\title{
So you think becoming a barrister is difficult? Try the French Bar!
}

\author{
by John Warwick Montgomery
}

I $\mathrm{t}$ is a commonplace that the French legal system is code based, in contrast with the case-law approach of the Anglo-American common law. True, common law jurisdictions depend more and more on codifications, and there are important areas of French law (for example, administrative law) in which case lawjurisprudence is the French term - predominates. But overall the generalisation holds. This is true for the rules of admission as an avocat: they are expressly set forth in a series of laws and decrees collected in the Nouveau Code de Procédure Civile - the Law of December 31, 1971, Article 11 ff.; the Decree of November 27, 1991, Article 42 ff, 99 and 100; and the "RIN" (the Décision of the National Council of the Bars of France, 2005, which has normative legal force). Since there is no single national French Bar (the Bars are regional, half of all French lawyers belonging to the Paris Bar), the individual Bars can and do supplement the RIN regulations with their own réglements intérieurs permitted as long as these do not conflict with the national rules.

So how does one become an avocat? The answer is a bit like the answer to the question, "How do nudists dance?": Carefully, very carefully. In point of fact, there are several answers to the question, depending on one's particular status. If one is a French citizen or a foreigner wanting to obtain his or her legal training in France, the standard route consists of obtaining a master's degree in law (the former licence en droit), followed by an 18-month programme at a regional centre of professional training; the latter has both an entrance and a final examination, and the programme consists of courses, a major project, and an apprenticeship. Successful completion leads to the "CAPA" - the aptitude certificate allowing one to apply to become a member of a French Bar. It is noteworthy that exceptions of various kinds to these requirements exist for members of related professions; thus, a law professor at a French university will automatically be admitted to the Bar simply by virtue of his professorial rank.

But if one is a foreign lawyer - ie, not a French citizen but a legal practitioner in another country - all will depend on whether one is or is not a citizen of one of the EU countries or of a Member State of the European Economic Community (Switzerland being expressly included as well).

For the non-EU lawyer wishing to become a French avocat, the key issue is whether his or her country has Bar admissions rules reciprocal to those of France; if so, those rules will of course apply. If not - which is the usual situation - an examination (the celebrated "Article 100" test) is the only route available. This examination consists of two three-hour written papers, one in civil law, the other - at the candidate's choice - in administrative law, commercial law, employment law, or criminal law. These are followed by two oral examinations: one chosen by lot among two subjects - (1) civil, criminal or administrative procedure and (2) the French judicial system and its organisation - and the other, déontologie, ie, the nature, professional standards, and ethics of French legal practice. One must obtain an overall passing average (10 out of 20 points) and the examination can be taken only three times. If one passes, one has the right to be enrolled in any of the French regional Bars as an avocat in full standing.

For the non-French EU lawyer, the regime is different. If, say, a German or a UK lawyer simply wishes to plead a single case, he will be allowed to do so with the aid of a French practitioner (much like the pro hac vice rule in American jurisdictions, though that rule applies to a lawyer from one American State wishing to plead a single case in an American State where he/she is not a member of the Bar). Should the non-French EU lawyer wish to set up an office (primary or secondary) in France, this is possible but only if he or she joins a French Bar under one's legal title of origin; practice will be limited to that lawyer's foreign law and will not extend to giving advice on French law or to pleading in French tribunals.

Interestingly, this EU-directed arrangement was fought tooth and nail by French Bars, which did not want competition from other EU lawyers. And even more restrictive jurisdictions - Luxembourg being the archetypal example - tried all sorts of underhanded ruses to prevent foreign EU lawyers from even this limited Bar membership. When the Luxembourg Bar tried to augment 
the European Directive with a local language requirement (French, German, and Luxembourgish!), the European Court of Justice ruled that this was contrary to the spirit of the free establishment of European workers and against the clear intent of the Directive (decision of September 19, 2006).

But a non-French EU lawyer, even when he or she successfully enters into such an arrangement, is very obviously a second-class citizen. He or she must pay the full fees to the Bar that a French avocat pays and must fulfil the same annual continuing legal education requirements that apply to the French avocet - but one's name appears in small letters in a separate section of the Tableau des Avocats (the official regional listing) or in minuscule type in the Paris Bar directory.

And if the non-French lawyer wishes to become a fullfledged avocat? Here, two paths exist. The one appears simple and non-threatening: three years of practice in France, and no examinations! This possibility, to be sure, came about not through any French efforts (quite to the contrary) but by way of a European Directive of February 16, 1998 - which did not get transposed into French law until February 11, 2004! (It now comprises Articles 89 and 90 of the revised Law of December 31, 1971). The problem with this alternative is that the three years of required full-time practice need to be in "French law." But, being a foreign attorney, the non-French lawyer is not supposed to be practising French law! The text goes on to say that if there is insufficient evidence of such practice, the Bar to which he or she applies has the right to "evaluate the regular and effective character of the activity exercised, as well as the capacity of the candidate to pursue such." This, of course, leaves open a wide area of discretion to the local Bar - even though, technically, the burden of proof in rejecting the candidate falls on the Bar, not on the applicant.

The second route for the non-French EU lawyer to become an avocat is to pass "Article 99" examinations. These are set individually for each applicant, and can consist of up to four tests, depending on how closely the candidate's legal education and experience parallel the French model. One examination is always on the practice and ethics of the profession (déontologie). The others are specified from a list derived from the CAPA requirements; civil law is a standard - plus commercial law, administrative law, criminal law, and employment law. If four subjects are assigned, one of them (chosen by the National Council of the Bar, which sets the list for each candidate) must consist of a four-hour written examination. The other subjects are tested by oral examination before juries. Two examination periods maximum are now set each year, one in Paris, the other in Versailles; in Paris, the jury consists of three examiners (a law professor who is a specialist in the given subject, a former member of the Bar Council, and a practitioner), whereas Versailles employs five-member juries.
If the European lawyer comes from a Napoleonic Code jurisdiction (say, Italy) or from a strongly French-speaking area (say, Belgium), he/she may be required only to do an oral in one or two subjects (déontologie is always mandatory). But all UK lawyers (solicitors, barristers, Scottish advocates), being from common-law backgrounds - after all, even the civil-law Scots end up before the common-law Supreme Court of the United Kingdom - are required to do the maximum of four subjects, and this means at least the one four-hour written examination plus three oral examinations. The style of these examinations is not the "practical, problem-solving" style of the Article 100 examinations, but the academic, essay style of the French university curriculum, where, for example, in the legal area, one always divides one's answer into two major subsections! To pass, one must average 10 out of 20 in toto, and one can only sit for the examination three times.

And now, a personal word. After two years as a member of the Strasbourg Bar and three years a member of the Paris Bar - both under my foreign practising title of barrister-atlaw (England and Wales) - I applied to take the oath as a French avocat. My dossier was replete with evidence of my legal activity in France, chiefly in the area of my specialty, religious liberty litigation before the European Court of Human Rights in Strasbourg. I was informed that this was inadequate. Why? Because I could not show that my income derived principally from this practice. Of course it did not: I am a university professor and my legal work has been largely pro bono. I pointed out, using an article on the Paris Bar's own website, that historically the French Bar has valued unremunerated service in behalf of the poor and downtrodden. Indeed, the French Bar grew out of eleemosynary service by lawyers who were clergy. "Would a physician be less good a doctor if he treated patients for free?" I asked. I also reminded the powers-that-be that one of the differences between French lawyers and AngloAmerican lawyers is that the French avocat must not engage in any form of commercial activity. Indeed, an avocat cannot simultaneously be a member of any other profession (medicine, accountancy, etc) - with the exception of university teaching or a religious ministry. (A few years ago, in 2003, a young avocate was suspended for having played an accordion for money on a public street though this was reversed on appeal. My arguments were to no avail. I withdrew my application and determined to take the tougher route.

I was therefore left with the Article 99 examinations. In spite of my possessing four earned law degrees, including the LLD - the higher doctorate in law - from Cardiff University, the National Council of French Bars required me to pass the maximum of four examinations. Their only concession, on the basis of my practice in France, was to substitute criminal law for civil law as the four-hour written examination. The oral examinations required of me were in commercial law (with its independent Code de Commerce and separate commercial courts), administrative law 
(again, independent of the Code Civil, and having its own "supreme court," the Conseil d'Etat), plus, of course, déontologie. The subject of my four-hour paper in criminal law turned out not to be any of the traditional, classical areas (crimes against the person, against property, against the state or against humanity), but "the criminal liability risks of corporations"!

I passed. Then, in completing the paper work for admission as an avocat à la cour (Paris), I was told that my contrat de collaboration with my colleagues in chambers had to be revised to state a minimum monthly salary! (This may be justified to prevent young associates from falling into slavery, but it again smacked of an unrecognized commercialism in a profession officially opposing filthy lucre as having anything to do with its nature). But, all of this having been finally resolved, I took the oath to become an avocat in an impressive ceremony in the First Chamber of the Palais de Justice's Court of Appeal - where the trial of Pétain had been held following the liberation of Paris and the defeat of the Nazis.

Was it worth it? Of course. But never think that lawyers are lacking in old fashioned territorialism - even when it goes against there own principles. The oath of the avocat pledges him or her not only to "dignity," "conscientiousness," "independence," and "honesty" but also to "humanity." Surely "humanity" should embrace greater appreciation of the high legal standards of our European states in general, as well as (why not?) the recognition that a lawyer can be a fine practitioner even if he is not well remunerated for it.

\section{John Warwick Montgomery}

Professor Emeritus of Law and Humanities, University of Bedfordshire;

Distinguished Professor, Patrick Henry College (Virginia, USA). 